Research Article

\title{
Estimating Impact of Salinity on Soil Water Potential Dynamics using a Novel Approach
}

\author{
Tariq Mahmood Khalil ${ }^{1,2 *}$, Muhammad Ajmal ${ }^{3}$, Iftikhar Zeb ${ }^{1,4}$ and Muhammad Azeem Khan ${ }^{1,5}$
}

${ }^{1}$ Department of Biological Systems Engineering, Washington State University; ${ }^{2}$ Office of the Research Innovation and Commercialization, University of Engineering and Technology, Peshawar, 25120, Pakistan; ${ }^{3}$ Department of Agricultural Engineering, University of Engineering and Technology, Peshawar, 25120, Pakistan; ${ }^{4}$ Department of Biotechnology, COMSATS University Islamabad, Abbottabad Campus; ${ }^{5}$ Applied Agricultural Remote Sensing Center, University of Nerw England, Armidale 2351 NSW, Australia.

\begin{abstract}
Limited fresh irrigation water is a resource constraint to agricultural productivity enhancement in water scarce areas of the globe. The farmers in these areas especially in the developing countries are using saline water for irrigation. This laboratory scale study was aimed to investigate the effects of saline water irrigation on development of total water potential within coarse and fine textured soils using a novel method based on water potential dynamics. Chilled mirror dew point hygrometer accurately captured the water potential dynamics when soil samples were irrigated with saline water. The instrument output showed that soil texture has profound effect on soil total water potential rising the water potential up to -4.56 for coarse soil and -9.11 MPa for fine textured soil. The instrument recorded a slow salt buildup in the coarse textured sandy soil which finally achieved a steady state after exhausting its maximum adsorption capacity. Whereas in the fine textured silt loam soil, a decreasing trend for the total water potential was recorded. The conversion of osmotic potential and electrical conductivity has been already been researched and the readings are interchangeable if conversion is desired. This method can be used as an alternative to the existing traditional methods for measuring the soil salinity. It is also expected that this technique will also help in calibrating the existing salinity measuring devices and may minimize the influence of bias or prejudice induced due to instrumental errors.

Received: August 22, 2020; Accepted: December 10, 2020; Published: December 19, 2020

*Correspondence: Tariq M. Khalil, Department of Biological Systems Engineering, Washington State University; Email: tariqkhalil@ uetpeshawar.edu.pk

Citation: Khalil, T.M., M. Ajmal, I. Zeb and M.A. Khan. 2020. Estimating impact of salinity on soil water potential dynamics using a novel approach. Journal of Engineering and Applied Sciences, 39(2): 154-163.

DOI: http://dx.doi.org/10.17582/journal.jeas/39.2.154.163

Keywords: Salinity, Water potential, Hygrometer, Osmotic potential, Electrical conductivity
\end{abstract}

\section{Introduction}

Soil salinity is the most vicious environmental factor (Akramkhanov et al., 2010) adversely affecting the agricultural productivity (Shrivastava and Kumar, 2015). Although its accurate estimation is difficult, the salinized soils area is increasing globally and affecting irrigated soils intensely. An estimated 6\% of the world's land is already facing salinity problems (Silva et al., 2010). About 20\% (45 million-ha) of cultivated land and $33 \%$ of irrigated agricultural land, producing one third of the world's food, is salt affected (Machado and Serralheiro, 2017; Shrivastava and Kumar, 2015). Salt accumulation is destroying approximately 10 million-ha agricultural land annually (Pimentel et al., 2004). Moreover, the salinized areas are increasing at a rate of $10 \%$ annually across the globe for several reasons, including weathering of native rocks, low 
precipitation, irrigation with saline water, high surface evaporation and poor cultural practices (Shrivastava and Kumar, 2015). This rate can be aggravated by excessive use of groundwater, intensive irrigation farming, climate change, increasing use of lowquality irrigation water, and poor drainage. Similarly, the tendency to increase the water productivity in the water scarce regions and using the low-quality water can lead to the accumulation of salts in the soil by reducing leaching fraction (Machado and Serralheiro, 2017). Bartels and Sunkar (2005) studied that, by 2050, salinity will affect half of the world's arable land.

Investigations (Bernstein, 1974; Machado and Serralheiro, 2017) reveal that salinity affects the plant growth in two ways. First, the amount of dissociated salts beyond a threshold value could be toxic for most of the plant species. Secondly, high salt concentration decreases the osmotic potential of soil water, eventually decreasing the total soil water potential $\left(\psi_{\mathrm{s}}\right)$. Hence the impact of salinity on plant growth reduction is a time-dependent process (Machado and Serralheiro, 2017). Salt accumulation induced osmotic stress in the root zone disrupts in up taking of essential elements such as $\mathrm{K}^{+}, \mathrm{Ca}^{2+}$, and $\mathrm{NO}_{3}{ }^{-}$and the accumulation of $\mathrm{Na}^{+}$and $\mathrm{Cl}^{-}$(Paranychianakis and Chartzoulakis, 2005). The accumulation of harmful ions may constraint photosynthesis, damage chloroplasts and other organelles and inactivate enzymes (Taiz and Zeiger, 2002). In saline soils, photosynthesis is affected by reduced $\mathrm{CO}_{2}$ availability because of diffusion limitations and as a result limiting the plant ability to grow (Flexas et al., 2007). Visual symptoms of salt stress induced plant injuries during plant growth appear progressively. In the first phase, the salt stress results in stunted growth, wilting and yellowed leaves. Subsequently, the damage reveals as leaf tip burning and necrosis of leaves, chlorosis of green parts, and the oldest leaves display scorching (Shannon and Grieve, 1998). Similarly, a reduction in plant biomass and leaf area has been observed in different vegetable crops under salt stress (Giuffrida $e t$ al., 2013). However, root biomass was found generally less affected by excess salinity than aboveground plant parts (Munns and Tester, 2008).

The convection diffusion equation states that solute transport in soil depends on a number of textural parameters that include hydraulic conductivity, tortuosity factor and soil moisture release curve (Darrah, 2001). It is hypothesized that soil texture effects the formation of osmotic $\left(\psi_{\mathrm{o}}\right)$ gradients between bulk soil and the root surface. Knowledge of such gradients is important to evaluate water availability in the soil-plant-atmosphere continuum (SPAC). Table 1 reports typical values for the hydraulic properties of two contrasting soil textures.

To narrow the gap between freshwater availability and demand in arid and semi-arid regions, the use of saline water of marginal quality is becoming an important consideration for crop production (Murtaza et al., 2006). In these areas, majority of crops are grown under irrigation. Similarly, inadequate irrigation management further deteriorates the problem and leads to secondary salinization. Irrigated agriculture is a major anthropogenic activity, which often leads to secondary salinization of land in arid and semiarid conditions (Shrivastava and Kumar, 2015). For irrigation, water salinity is commonly expressed in terms of electrical conductivity, $\mathrm{EC}\left(\mathrm{dS} \mathrm{m}^{-1}\right)$. Its values range from 0.6 for fresh water to 1.5-3.0 for brackish water to about $51 \mathrm{dS} \mathrm{m}^{-1}$ in sea water (Arsalan et al., 2018; Mostafa et al., 2015). High concentrations of salt in the soil cause physiological drought condition. Even though the field appears to have plenty of moisture, the plants wilt because the roots are unable to absorb the water due to the high osmotic potential (Fipps, 2003).

The total potential of soil water is the sum of matric and osmotic potential. The osmotic component of soil water potential is due to the presence of soluble salt in water. If the pore water is interconnected, equilibrium conditions will result in a uniform ion concentration throughout the soil. The matric potential is the fraction of soil water energy associated with the interaction between liquid water and solid particles. Matric suction or potential is due to the surface adsorptive forces of the soil. The relations between total, osmotic and matric potential is given by the following equation (Campbell and Norman, 1997; Gimenez et al., 2005).

$$
\psi_{t}=\psi_{m}+\psi_{o} \quad \ldots .(1)
$$

Irrigation water quality has profound impact on crop production (Grattan, 2002). About $65-75 \%$ of world's fresh water is used in agriculture. Due to population outburstand high living standards, the demand for fresh water is increasing around the globe and is different due to uneven distribution of water resources and 
Table 1: Soil Hydraulic Properties.

\begin{tabular}{|c|c|c|c|c|c|c|}
\hline Texture & $\begin{array}{l}\text { Saturation } \\
\left(m^{3} m^{-3}\right)\end{array}$ & $\begin{array}{l}\text { Bulk density } \\
\left(\mathrm{kg} \mathrm{m}^{-3}\right)\end{array}$ & $\begin{array}{l}\text { Saturated hydraulic } \\
\text { conductivity }\left(\mathrm{m} \mathrm{h}^{-1}\right)\end{array}$ & $\begin{array}{l}\text { Field capacity } \\
\left(\mathrm{m}^{3} \mathrm{~m}^{-3}\right)\end{array}$ & $\begin{array}{l}\text { Permanent wilting } \\
\text { point }\left(\mathrm{m}^{3} \mathrm{~m}^{-3}\right)\end{array}$ & $\begin{array}{l}\text { Plant available } \\
\text { water }\left(\mathrm{m}^{3} \mathrm{~m}^{-3}\right)\end{array}$ \\
\hline Sandy soil & 0.326 & 1.786 & 0.12043 & 0.116 & 0.045 & 0.071 \\
\hline Silt loam & 0.468 & 1.411 & 0.01868 & 0.286 & 0.106 & 0.180 \\
\hline
\end{tabular}

Source: James, 1988.

population densities. Per capita water requirement in nearly 80 countries, accounting for more than $40 \%$ of the world's population, has been decreased (Bennett, 2000). In the present climate change scenarios, irrigation water is a resource constrain to agricultural production growth, forcing farmers to use the saline water for crop production. Salinity not only reduces crop productivity but also reduces the crop selection choice (Qadir et al., 2003). Henson et al. (2006) estimated the crop yield reduction potential from the following expression.

$$
\% \text { Yield }=100-b\left(E C_{e}-a\right) \quad \ldots(2)
$$

Where; ECe is the average root zone soil salinity while $a$ and $b$ are coefficients of salinity threshold and slope, respectively, representing the percent loss in relative yield above the threshold. The osmotic potential stress is among the primary environmental concerns globally that limits the successful establishment of crop seed germination at early stages, including some genotypes of durum wheat (Maucieri et al., 2018). A study on tomato crop indicated significant yield reduction due to osmotic adjustment, maintaining the turgor potential and the stomatal conductance for the lower values of the leaf water potential (Katerji, 1998). Application of poor-quality saline water for crop production may pose serious threats to chemical and physical quality of soil. The soil and water salinity have direct effects on the water use efficiency of crops, crop growth, nutrients uptake and fixation and yield (Van Hoorn et al., 1993, 2001).

Salinity not only decreases the soil productivity, but also adversely affects the soil structures. Study carried out by (Mostafazadeh-Fard et al., 2007) indicates that use of saline water not only decreases the water holding capacity of soils but also decreases the leaching efficiency of soils. Hence proper management practices and understanding of salinity buildup in soil is required for safe use of saline and sodic waters on sustainable basis (Choudhary et al., 2011).

In this era of technological advancement, more sophisticated tools are widely used in today's agriculture, where the use of sensors equipped with advanced technology are the core of the system. This study is intended to explore an alternative approach to accurately measure the soil salinity using relative new approach. It is also expected that this technique will help in quick calibration of existing salinity measuring devices and may minimize the influence of bias or prejudice induced due to instrumental errors. The objective of this study was to investigate the water potential dynamics in fine and coarse soil textural classes at low gravimetric water content when irrigated with saline water using a novel technique.

\section{Materials and Methods}

\section{Chilled-mirror dew-point water potential meter}

The chilled mirror dew point hygrometer measures soil sample temperature and dew point which is utilized in measuring the water activity (Campbell et al., 2007). In this experiment the WP4C Water Potential Meter (Meter Group, 2019) was used to investigate the impact of salinity on water potential buildup induced by saline water. Previously in many research studies, chilled-mirror dew-point method has been used for determining the humidity and water retention curve of soils (Wang et al., 2003; Ali et al., 2014; Ferrari et al., 2014; Lu et al., 2017). Such kind of the instruments are best suited for measuring the water potential of very dry soils (Gee et al., 1992) when hydraulic conductivity of the soil sample is very much low for water equilibration to occur (Gee et al., 2002). The schematic of the chilled-mirror dew-point device is shown Figure 1.

The soil sample is placed in $38 \mathrm{~mm}$ diameter and 11 $\mathrm{mm}$ high cup which is inserted into a sealed chamber for achieving a vapor equilibrium with the ambient conditions. To reduce the equilibrium time, the chamber is equipped with a fan to circulate air within the sample. The sample chamber was equipped with an infrared thermometer for measuring the incubated sample temperature. A high precision cooled surface referred as Chilled Mirror where upon vapor 
condensation is made and the dew point temperature is detected by an optical sensor. The recommended temperature for the soil sample is between $5{ }^{\circ} \mathrm{C}$ and $40{ }^{\circ} \mathrm{C}$. The equipment can measure the water potential in the range of 0 to $-300 \mathrm{MPa}$ with an accuracy of $\pm 0.05 \mathrm{MPa}$ from 0 to $-5 \mathrm{MPa}$ and $1 \%$ from -5 to $-300 \mathrm{MPa}$. The equipment was periodically calibrated using a fresh sample of 0.5 molal $\mathrm{KCl}$ and adjustment were made for any drift in water potential.

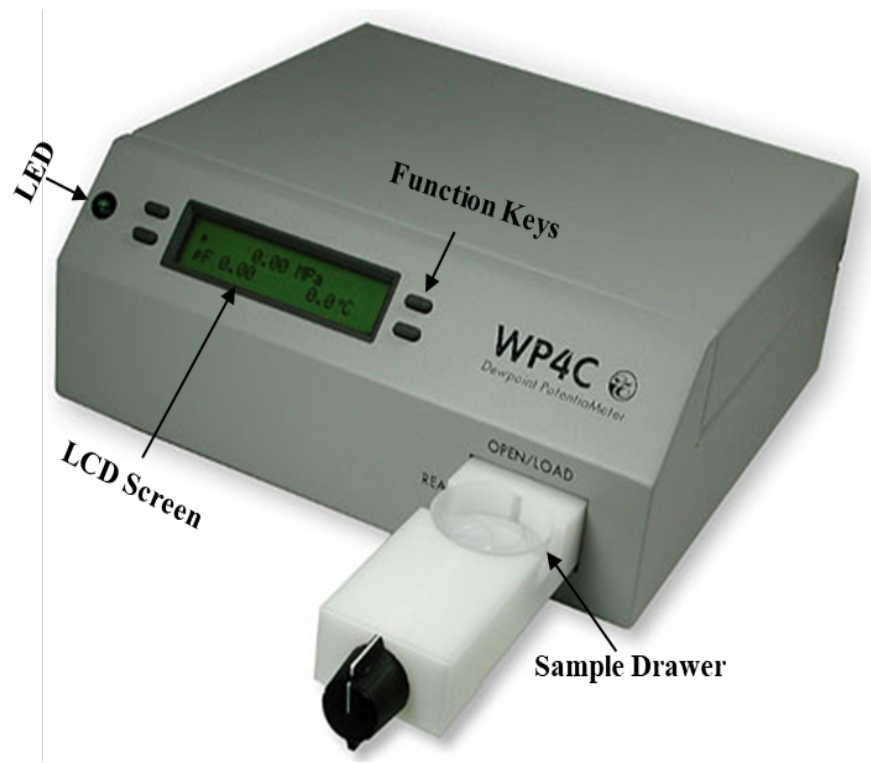

Figure 1: Schematic view of WP4C (Source: Meter Group, 2019).

\section{Soil sample collection}

The study was intended to investigate the impact of saline water use on surface salinity in two contrasting soil textures fine and coarse textured soils using dew point hygrometer. The soil samples were collected from Lewiston ID $\left(46.4004^{\circ},-117.0012^{\circ}\right) \mathrm{W}$ and Prosser $\left(46.2516^{\circ},-119.7387^{\circ}\right)$ WA, USA.

The soil sample collected from Lewiston is classified by the US Soil Conservation Services as coarse textured. The taxonomic class is at 1350 to $1372 \mathrm{~m}$ above the sea level and are formed in moderately coarse mixed sediment. These soils are irrigated croplands for fodder, small grains and pastures and stretched from southern Idaho to northern Utah.

The Prosser Warden silt loam soil has an average grain size distribution of 21,68 , and 11 percent for sand, silt and clay respectively. The soil is mainly formed glaciofluvial sediments with traces of volcanic ash. The Warden soils are suitable for grazing and irrigated crops and stretched over Southeastern and south-central Washington and north-central Oregon at 90 to $732 \mathrm{~m}$ from mean sea level.
Theoretical framework

The water potential was measured using WP4C dew point hygrometer by Decagon Technologies. The instrument uses the chilled-mirror dew point technique to measure the water potential of a sample. The machine can measure samples with internal temperature control from 15 to $40^{\circ} \mathrm{C}$. Similarly, it can measure the water potential from 0 to $-300 \mathrm{MPa}$ with a very high accuracy (Aujla and Paulitz, 2017). The soil sample is placed inside the sealed chamber with the mirror, the mirror is cooled until dew is formed, the dew point is detected with photoelectric cell. From dew point temperature the water potential of the air in the chamber, which is the same as the water potential of the sample, is determined. Thermocouple attached to the mirror recorded the temperature at which condensation occurred. The total potential of sample is found using the following relation (Campbell and Norman, 1997).

$$
\psi=\frac{R T}{M} \cdot \ln \frac{P}{P_{O}}
$$

$\mathrm{P}$ is vapor pressure of the air, $\mathrm{P}^{\circ}$ is the saturation vapor pressure, $\mathrm{R}$ is the universal gas constant (8.31 $\mathrm{J} / \mathrm{mol} \mathrm{K}$ ), T is sample temperature in Kelvin, and $\mathrm{M}$ is the molecular mass of water. The vapor pressure of the air was measured using a chilled mirror, and saturation vapor pressure was computed from sample temperature.

\section{Experimental design and data collection}

In order to investigate the effects of total water potential $(\psi)$, the total dissolved salts (TDS) concentration of selected soil samples were reduced to minimum. For this purpose, the mixture of soils was washed and soaked in distilled water for 48 hours.

Measured volume of sand and silt loam samples $(650 \mathrm{cc})$ were transferred to six PVC pots of 1000 cc capacity each. The PVC pots were perforated at the base to facilitate the drainage. Experiments were conducted in triplicates. $10 \mathrm{dS} / \mathrm{m}$ EC irrigation water was used to irrigate the soil samples. This irrigation water was prepared by mixing of $5.42 \mathrm{gm}$ of $\mathrm{NaCl}$ salt in distilled water at room temperature (USDA, 1954).

The water potential was measured at initial and intermittent stages for different salt concentrations at same gravimetric moisture content after each water application. The latter was accomplished by 
drying the soil samples first in oven at $105^{\circ} \mathrm{C}$ and then adding the water to bring it to the desired level of water content. All the samples were tested at 5\% gravimetric water content.

Table 2: Relation Between ECand gm of $\mathrm{NaCl}$ dissolved per $\mathrm{kg}$ of $\mathrm{H}_{2} \mathrm{O}$ (USD $\left.A, 1954\right)$.

$\begin{array}{ll}\mathbf{E C} @ 25{ }^{\circ} \mathbf{C}(\mathbf{d S} / \mathbf{m}) & \text { Sodium Chloride }\left(\mathrm{g} \mathrm{NaCl} / \mathrm{Kg} \mathrm{H}_{2} \mathrm{O}\right) \\ 0.1 & 0.0455 \\ 0.2 & 0.0935 \\ 0.5 & 0.2421 \\ 1 & 0.4970 \\ 2 & 1.0205 \\ 5 & 2.6413 \\ 10 & 5.4232 \\ 20 & 11.1351\end{array}$

\section{Results and Discussion}

\section{Water potential induced by saline water}

Before starting the experiment, the soil samples were washed with distilled water and soaked for 48 hours in distilled water. The initial total potential for fine and coarse textured soil was -0.68 and $-0.08 \mathrm{MPa}$ at $5 \%$ gravimetric water content, respectively. The higher initial residual salt content in fine textured soil is possibly due to its greater surface adsorption characteristics.

After first application of saline water, the total potential for fine texture soil decreased to $-5.42 \mathrm{MPa}$, which however, increased to $-3.26 \mathrm{MPa}$ after second irrigation. It is limited and difficult to characterize the exact nature of the soil solution in drying soils. However, depending on soil type, different techniques employed have identified that water volume of soil solution can be extracted to water potentials of $-0.23 \mathrm{MPa}$ (Dyer et al., 2008). Since most plants are able to extract soil water from $-1.5 \mathrm{MPa}$, the precise existence of the soil solution composition remains unknown and can only be calculated on the basis of theoretical predictions based on soil chemistry and physical properties. Evidence from current methods however show a range of soil solution concentration during soil drying that have established several mechanisms contributing to salt removal from the soil solution (Sheldon et al., 2017).

An increase in the total potential is also attributed to rise in temperature. However, a controlled microenvironment which is feasible for microorganism activities should be provided to avoid difficulties in measuring water potential (Aujla and Paulitz, 2017). Proper measurement of the water potential induced by saline water is essential to manage the microenvironment of the soil for proper crops growth. Improper saline water irrigation and inaccurate soil water potential could lead to damage crops. Phogat et al. (2018) found that increasing salt concentration in the plant root zone has an increasing osmotic impact and reduces roots' water uptake, which in turn affects many physiological plant processes like photosynthesis and transpiration, water potential for stem and leaf, and net assimilation rate. The undesirable impacts of increased salinity and water stresses on physiological traits are transmitted into the fruit yield reduction. Similarly, the unchecked fluctuation in individual ions such as $\mathrm{Cl}^{-}$or $\mathrm{Na}^{+}$may sometimes rise to a toxic level and disrupt plant metabolism.

The initial increase followed by a decrease of total potential might be due to accumulation of salts in the upper layers of fine texture soil and then leaching down on the second irrigation. Finally, after third irrigation the salt content started building up again at a steady rate. The response of both fine and coarse texture is provided in Figures 2 and 3.

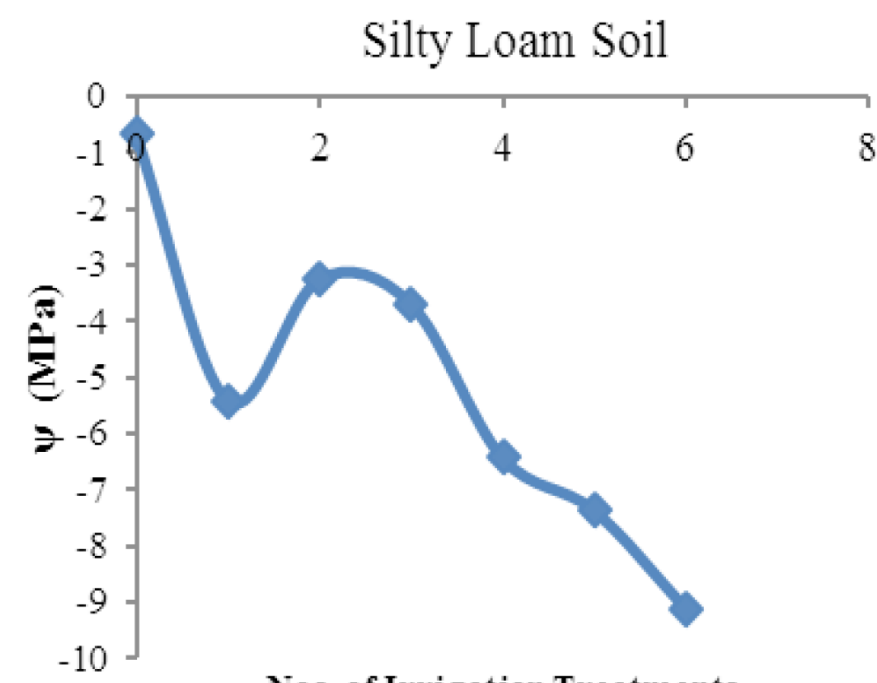

Nos. of Irrigation Treatments

Figure 2: Total Water Potential Response of Silt Loam Soil to Saline Water Application of $10 \mathrm{dS} / \mathrm{m} \mathrm{EC}$.

The rate of total water potential buildup was found higher in course texture soil in comparison to the fine texture soil. This is because the course soil dries quickly providing an opportunity to the salt contents rise which in agreement with the findings of $\mathrm{Abd}$ El-Mageed et al. (2016) mentioning that during the 
drying process, salts move up in areas with saline water irrigation which creates an undesirable environment for plant growth. After fifth application the total matric potential reached steady state for coarse texture having no further increase or decrease in the total water potential. The possible reason for this behavior would be that with further water applications the soil reached to the maximum adsorption capacity and extra salts were leached out from the soil profile.

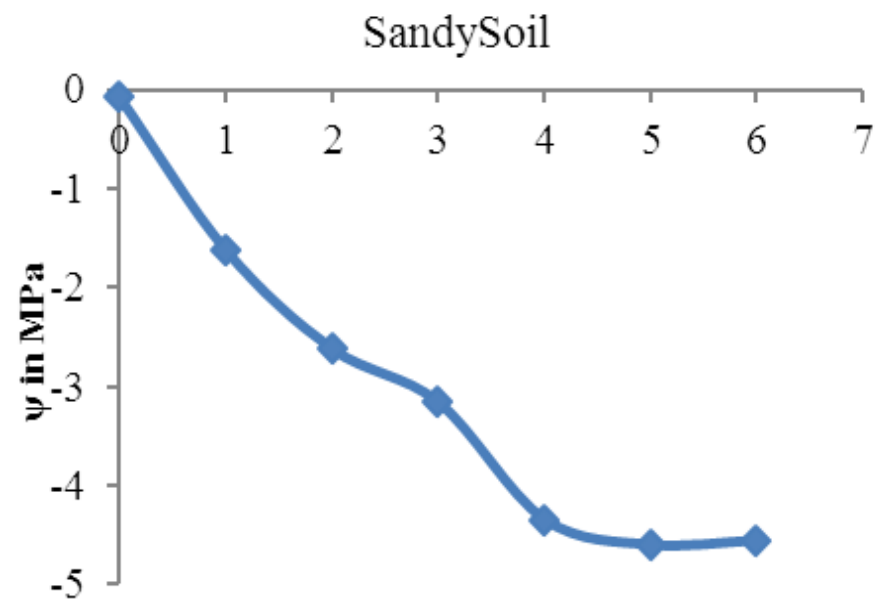

Nos. of Irrigation Treatments

Figure 3: Total water potential response of sandy soil to saline water application of $10 \mathrm{dS} / \mathrm{m} E C$.

The result of this study for total water potential measurement is supported by the finding of Van Hoorn et al. (1993) after saline water application in loam soil for potatoes crop, with soil water potential increasing at each irrigation and afterwards decreasing. For two saline water treatments in clayey soil, the salinity was found less than the loamy soil. Accordingly, the water potential measured with a water activity meter and a Richards' thermocouple psychrometer exhibited almost similar trend (Gee et al., 1992). A very similar trend was found for water retention functions of heat dissipation porous matrix material used to measure the soil water matric potential (Dane et al., 2002). Likewise, the findings of Dasberg et al. (1991) show that saline water application increased potential for soil water before irrigation and reduced potential for leaf water. For effective saline irrigation, Wiesman (2009) investigated that increasing the irrigation frequency will reduce the salt concentration and minimizing the osmotic potential. Measuring osmotic potential is very much difficult than measuring matric potential (Campbell, 1988). To avoid this problem, the WP4C device provide direct measurement of total water potential.

\section{Relation between the water potential and $E C$}

The osmotic potential and electrical conductivity have linear relation when measured at soil saturations, for typical soils they are related with an assumption that the interaction between different species of solutes is apparently negligible (Papendick and Campbell, 1981).

$$
\psi_{o s}=-36 E C_{s} \quad \ldots \ldots(4)
$$

Where; $\psi_{\text {os }}$ and $\mathrm{EC}_{\mathrm{s}}$ is osmotic potential and electrical conductivity of the soil saturation extract respectively. The osmotic potential varies with the moisture content and could be estimated at any soil moisture content using following relation (Smagin et al., 2018).

$$
\psi_{o}=\psi_{o s} \theta_{s} / \theta
$$

$\psi_{\mathrm{o}}$ is osmotic potential at given moisture content, $\theta_{\mathrm{s}}$ is saturation moisture content, while $\theta$ is moisture content.

Potential advantages of osmotic potential approach over electrical conductivity

Previously considerable efforts have been made for better quantitative understanding of plant response to salinity. Research has been conducted and much knowledge has been acquired on physiological processes associated with salinity and/or to specific ions. The question whether the osmotic potential is more suitable than the $\mathrm{EC}$ while evaluating the whole plant response to salinity has been investigated. Typically, salinity is expressed in terms of electrical conductivity of the soil saturates to investigate the impact of various ionic species on crop growth. Most of the repositories on plant growth response thresholds to soil and water salinity are based on the electrical conductivity values. There is also difference of opinion on salts and nutrients induced osmotic potential and toxic impacts of salinity. This is obvious since the presence of additional salts leads to positive effects on plant growth, though it intensifies osmotic gradients. Furthermore, in saline solutions the ionic activities might be much lower than the expected from their concentrations. This is because of the formation and precipitation of ion pairs. Therefore, the while considering the impact of salinity on crop growth and response must take into account ion combinations. Research (Ben-Gal et al., 2009) shows that in attempts to differentiate between the osmotic and 
toxic effects of salinity, normalizing the whole-plant response to salinity may be well presented in terms of the osmotic potential of the soil saturate rather than electrical conductivity. The detailed data on soil total water potential dynamics for the experiment period is provided in the supplementary data Table 1.

\section{Conclusions and Recommendations}

Chilled mirror dew point hygrometer accurately captured the water potential dynamics when soils samples were irrigated with saline water. The instrument's output showed that soil texture has profound effect on soil total water potential that rose to -4.56 and $-9.11 \mathrm{MPa}$ for coarse and fine textured soils, respectively. A slow salt buildup was observed in coarse texture sandy soil which finally achieved a steady state after exhausting its maximum adsorption capacity. Whereas in the fine textured silt loam soil a decreasing trend for the total water potential was recorded. The method has the advantage over the traditional electrical conductivity method as it normalizes the plant response to salinity. The conversion of osmotic potential and electrical conductivity has already been researched and the readings are interchangeable if conversion is desired.

\section{Acknowledgments}

The authors wish to thank Dr. Paolo Castiglione and Dr. Colin S. Campbell for providing technical support and helpful discussion throughout the experiment. The authors also extend their gratitude to $\mathrm{R}$ and D Section of Decagon Devices, Pullman, WA for proving chemicals and equipment for conducting this experiment and Biological Systems Engineering, Washington State University for provision of laboratory space.

\section{Novelty Statement}

The technique presented in this study is a new approach for measuring the electrical conductivity. It can also be used in calibrating the existing indirect salinity measuring devices by minimizing the influence of bias or prejudice induced due to instrumental errors.

\section{Author's Contribution}

Tariq Mahmood Khalil designed and conducted experiment and drafted the article; Muhammad Ajmal carried out technical review of the article, performed proof reading and supported in in literature review; Iftikhar Zeb supported the principle author in data collection; and Muhammad Azeem Khan provided support in final review of the article

\section{Supplementary material}

There is supplementary material associated with this article. Access the material online at: http://dx.doi. org/10.17582/journal.jeas/39.2.154.163

\section{Conflict of interest}

The authors have declared no conflict of interest.

\section{References}

Abd El-Mageed,T.A.,W.M.Semida and M.H.Abd El-Wahed. 2016. Effect of mulching on plant water status, soil salinity, and yield of squash under summer-fall deficit irrigation in saltaffected soil. Agric. Water Manage., 173: 1-12. https://doi.org/10.1016/j.agwat.2016.04.025

Akramkhanov, A., M. Ibrakhimov and J. Lamers. 2010. Managing soil salinity in the lower reaches of the Amudarya delta: how to break the vicious circle. Case Study \#8-7. Food policy for developing countries: Case studies. Online available at: https://hdl.handle.net/1813/55718

Ali, M.A., R.M. Singh, A. Bouazza, W.P. Gates and R.K. Rowe. 2014. Variation of total suction of a clayey soil with temperature. Proc. $6^{\text {th }}$ Int. Conf. Unsaturated Soils, 1: 849-855. https:// doi.org/10.1201/b17034-121

Arslan, H., M.S. Kiremit and A. Güngör. 2018. Impacts of different water salinity levels on salt tolerance, water use, yield, and growth of chives (Allium schoenoprasum). Commun. Soil Sci. Plant Anal., 49(20): 2614-2625. https://doi.or g/10.1080/00103624.2018.1526949

Aujla, I.S. and T.C. Paulitz. 2017. An improved method for establishing accurate water potential levels at different temperatures in growth media. Front. Microbiol., 8: 1497. https://doi. org/10.3389/fmicb.2017.01497

Bartels, D. and R. Sunkar. 2005. Drought and salt tolerance in plants. Crit. Rev. Plant Sci., 24(1): 23-58. https://doi. org/10.1080/07352680590910410

Ben-Gal, A., H. Borochov-Neori, U. Yermiyahu and U. Shani. 2009. Is osmotic potential a 
more appropriate property than electrical conductivity for evaluating whole-plant response to salinity? Environ. Exp. Bot., 65(23): 232-237. https://doi.org/10.1016/j. envexpbot.2008.09.006

Bennett, A.J., 2000. Environmental consequences of increasing production: some current perspectives. Agric. Ecosyst. Environ., 82(13): 89-95. https://doi.org/10.1016/S01678809(00)00218-8

Bernstein, L., 1974. Crop growth and salinity. In: Drainage for Agriculture. J. van Schilfgaarde (ed.). Agronomy, 17: 39-54. https://doi. org/10.2134/agronmonogr17.c3

Campbell, G.S. and J.M. Norman. 1997. An introduction to environmental biophysics, Springer, New York. https://doi. org/10.1007/978-1-4612-1626-1

Campbell, G.S., 1988. Soil water potential measurement: An overview. Irrig. Sci., 9(4): 265-273.https://doi.org/10.1007/BF00296702

Campbell, G.S., D.M. Smith and B.L. Teare. 2007. Application of a dew point method to obtain the soil water characteristic. In: Experimental unsaturated soil mechanics, Springer, Berlin, Heidelberg. pp. 71-77. https://doi. org/10.1007/3-540-69873-6_7

Choudhary, O.P., S.R. Grattan and P.S. Minhas. 2011. Sustainable crop production using saline and sodic irrigation waters. In: Alternative farming systems, biotechnology, drought stress and ecological Fertilisation, springer, Dordrecht, pp. 29-318. https://doi.org/10.1007/978-94007-0186-1_10

Dane, J.H., C.G. Topp, B.R. Scanlon, B.J. Andraski and J. Bilskie. 2002. Miscellaneous methods for measuring matric or water potential. In: Methods of soil analysis: Part 4 Physical Methods, SSSA Book Series, Soil Science Society of America.

Darrah, P.R., 2001. Modeling the Rhizosphere. In: R. Pinton, the Rhizosphere, New York: Marcel Dekker, pp. 327-372.

Dasberg, S., H. Bielorai, A. Haimowitz and Y. Erner. 1991. The effect of saline irrigation water on "Shamouti" orange trees. Irrig. Sci., 12(4): 205-211.https://doi.org/10.1007/BF00190525

Dyer, C.L., P.M. Kopittke, A. Sheldon and N.W. Menzies. 2008. Influence of soil moisture content on soil solution composition. Soil Sci. Soc. Am. J., 72(2): 355-361. https://doi. org/10.2136/sssaj2007.0124

Ferrari, A., V. Favero, P. Marschall and L. Laloui. 2014. Experimental analysis of the water retention behaviour of shales. Int.J. Rock Mech. Min. Sci., 72: 61-70. https://doi.org/10.1016/j. ijrmms.2014.08.011

Fipps, G., 2003. Irrigation water quality standards and salinity management strategies. The Texas $A$ and M University System, College Station, Texas 77843-2117, Report No B-1667.

Flexas, J., A. Diaz-Espejo,J. Galmés, R. Kaldenhoff, H. Medrano and M. Ribas-Carbo. 2007. Rapid variations of mesophyll conductance in response to changes in $\mathrm{CO}_{2}$ concentration around leaves. Plant Cell Environ., 30(10): 1284-1298.https:// doi.org/10.1111/j.1365-3040.2007.01700.x

Gee, G.W., A.L. Ward, Z.F. Zhang, G.S. Campbell and J. Mathison. 2002. The influence of hydraulic nonequilibrium on pressure plate data. Vadose Zone J., 1(1): 172-178. https:// doi.org/10.2113/1.1.172

Gee, G.W., M.D. Campbell, G.S. Campbell and J.H. Campbell. 1992. Rapid measurement of low soil water potentials using a water activity meter. Soil Sci. Soc. Am. J., 56(4): 1068-1070. https://doi.org/10.2136/ sssaj1992.03615995005600040010x

Gimenez, C., M. Gallardo and R.B. Thompson. 2005. Plant water relations. Encycl. Soils Environ., pp. 231-238. https://doi.org/10.1016/ B0-12-348530-4/00459-8

Giuffrida, F., D. Scuderi, R. Giurato and C. Leonardi. 2013. Physiological response of broccoli and cauliflower as affected by $\mathrm{NaCl}$ salinity. Acta Hortic., 1005: 435-441. https:// doi.org/10.17660/ActaHortic.2013.1005.52

Grattan, S., 2002. Irrigation water salinity and crop production. UCANR Publications. Vol. 9. https://doi.org/10.3733/ucanr.8066

Hanson, B., S.R. Grattan and A. Fulton. 2006. Agricultural salinity and drainage. University of California Irrigation Program, University of California, Davis.

James, L.G., 1988. Principles of farm irrigation systems design. John Wiley and Sons Limited, USA.

Katerji, N.V., 1998. Response of tomatoes, a crop of indeterminate growth, to soil salinity. Agric. Water Manage., 38(1): 59-68. https://doi. org/10.1016/S0378-3774(98)00051-1

Lu,Y.,H.Abuel-Naga and A.Bouazza.2017.Water 
retention curve of GCLs using a modified sample holder in a chilled-mirror dew-point device. Geotext. Geomembr., 45(1): 23-28. https:// doi.org/10.1016/j.geotexmem.2016.08.003

Machado, R.M.A. and R.P. Serralheiro. 2017. Soil salinity: Effect on vegetable crop growth management practices to prevent and mitigate soil salinization. Horticulturae, 3(2): Article No. 30. https://doi.org/10.3390/ horticulturae 3020030

Maucieri, C., C. Caruso, S. Bona, M. Borin, A.C. Barbera and V. Cavallaro. 2018. Influence of salinity and osmotic stress on germination process in an old Sicilian landrace and a modern cultivar of Triticum Durum Desf. Cereal Res. Commun., 46(2): 253-262. https:// doi.org/10.1556/0806.46.2018.07

Meter Group, 2019. WP4C dewpoint potentiometer, operator's manual. Decagon Devices Inc. Pullman, WA, USA

Mostafa, M.R., S.S. Mervat, R.E.L. Safaa, M.A.E. Ebtihal and T.A. Magdi. 2015. Exogenous $\alpha$-tocopherol has a beneficial effect on Glycine $\max ($ L.) plants irrigated with diluted sea water. J. Hortic. Sci. Biotechnol., 90(2): 195-202. https://doi.org/10.1080/14620316.2015.11513 172

Mostafazadeh-Fard, B.E., M.A. Heidarpour, A.B. Aghakhani and M.O. Feizi. 2007. Effects of irrigation water salinity and leaching on soil chemical properties in an arid region. Int. J. Agric. Biol., 9(3): 166-462.

Munns, R. and M. Tester. 2008. Mechanisms of salinity tolerance. Ann. Rev. Plant Biol., 59: 651-681. https://doi.org/10.1146/annurev. arplant.59.032607.092911

Murtaza, G., A. Ghafoor and M. Qadir. 2006. Irrigation and soil management strategies for using saline-sodic water in a cottonwheat rotation. Agric. Water Manage., 81(1-2): 98-114. https://doi.org/10.1016/j. agwat.2005.03.003

Papendick, R.I. and G.S. Campbell. 1981. Theory and measurement of water potential. Water Potential Relat. Soil Microbiol., 9: 1-22. https://doi.org/10.2136/sssaspecpub9.c1

Paranychianakis, N.V. and K.S. Chartzoulakis. 2005. Irrigation of Mediterranean crops with saline water: from physiology to management practices. Agric., Ecosyst. Environ., 106(23): 171-187. https://doi.org/10.1016/j. agee.2004.10.006

Phogat, V., J.W. Cox and J. Šimůnek. 2018. Identifying the future water and salinity risks to irrigated viticulture in the Murray-Darling Basin, South Australia. Agric. Water Manage., 201: 107-117. https://doi.org/10.1016/j. agwat.2018.01.025

Pimentel, D., B. Berger, D. Filiberto, M. Newton, B. Wolfe, E. Karabinakis, S. Clark, E. Poon, E. Abbett and S. Nandaopal. 2004. Water resources: Agricultural and environmental issues. BioScience, 54(10): 909-918.https://doi. org/10.1641/0006-3568(2004)054[0909:WR AAEI]2.0.CO;2

Qadir, M., T.M. Boers, S. Schubert, A. Ghafoor and G. Murtaza. 2003. Agricultural water management in water starved countries: challenges and opportunities. Agric. Water Manage., 65(3): 165-185. https://doi. org/10.1016/S0378-3774(03)00146-X

Shannon, M.C. and C.M. Grieve. 1998. Tolerance of vegetable crops to salinity. Sci. Hortic., 78(1-4): 5-38. https://doi.org/10.1016/S03044238(98)00189-7

Sheldon, A.R., R.C. Dalal, G. Kirchhof, P.M. Kopittke and N.W. Menzies. 2017. The effect of salinity on plant available water. Plant Soil, 418(1-20): 477-491. https://doi.org/10.1007/ s11104-017-3309-7

Shrivastava, P. and R. Kumar. 2015. Soil salinity: A serious environmental issue and plant growth promoting bacteria as one of the tools for its alleviation. Saudi J. Biol. Sci., 22(2): 123-131. https://doi.org/10.1016/j.sjbs.2014.12.001

Silva, E.N., R.V. Ribeiro, S.L. Ferreira-Silva and J.A.G. Silveira. 2010. Comparative effects of salinity and water stress on photosynthesis, water relations and growth of Jatropha curcas plants. J. Arid Environ., 34(10): 1130-1137. https://doi.org/10.1016/j.jaridenv.2010.05.036

Smagin, A.V., N.B. Sadovnikova, A.V. Kirichenko, Y.V. Egorov, V.G. Vityazev and A.S. Bashina. 2018. Dependence of the osmotic pressure and electrical conductivity of soil solutions on the soil water content. Eur. Soil Sci., 51(12): 1462-1473. S1064229318120128

Taiz, L. and E. Zeiger. 2002. Plant physiology, Sinauer: Sunderland, UK, pp. 690.

USDA, 1954. Diagnosis and improvement of saline and alkali soils. Agricultural Handbook No. 
60, United States Department of Agriculture, Washington DC, USA.

Van Hoorn, J.W., N. Katerji, A. Hamdy and M. Mastrorilli. 1993. Effect of saline water on soil salinity and on water stress, growth, and yield of wheat and potatoes. Agric. Water Manage., 3(23): 247-265. https://doi.org/10.1016/03783774(93)90032-6

Van Hoorn, J.W., N. Katerji, A. Hamdy and M. Mastrorilli. 2001. Effect of salinity on yield and nitrogen uptake of four grain legumes and on biological nitrogen contribution from the soil. Agric. Water Manage., 51(2): 87-98. https://doi.org/10.1016/S0378-
3774(01)00114-7

Wang, J., D.J. Carlson, D.B. Parsons, T.F. Hock, D. Lauritsen, H.L. Cole, K. Beierle and E. Chamberlain. 2003. Performance of operational radiosonde humidity sensors in direct comparison with a chilled mirror dew $\bigotimes$ point hygrometer and its climate implication. Geophys. Res. Lett., 30(16): Article No. 1860. https://doi.org/10.1029/2003GL016985

Wiesman, Z., 2009. Desert olive oil cultivation: advanced bio technologies ( $1^{\text {st }}$ Edition), Chapter 7 - Desert-suitable genetic material. Academic Press, USA.pp. 135-183. https://doi. org/10.1016/B978-0-12-374257-5.00007-5 